Jacek Bylica ${ }^{1}$ (iD) http:/orcid. org/0000-0003-4680-0233

Jagiellonian University

\title{
TOWARDS THE SOCIAL AND CULTURAL INTEGRATION: AROUND THE BOOK SOCIAL SERVICES IN WORK WITH REFUGEES ON POLISH GERMAN CROSS-BORDER REGION (ISBN 978-83-7867-771-0)
}

The reviewed publication Social Services in Work with Refugees on Polish German Cross-Border Region / Stużby społeczne w pracy z uchodźcami na pograniczu polsko-niemieckim edited by Barbara Kromolicka and Anna Linka, Szczecin: Volumina.pl Daniel Krzanowski 2018, pp. 156, contains four theoretical texts, ten articles showing practical solutions in work with refugees and migrants, and a report on the implementation of a scientific and educational project focused on the refugee issue. Such a construction allows for a cross-sectional view of the issue, especially since the authors of the texts are representatives of various social sciences and practitioners working directly in the field, which gives the publication an interdisciplinary character. The territorial area of the analysis, i.e. the Polish-German cross-border region, is also not without significance. It turns out that Szczecin, and more broadly the West Pomeranian Voivodeship has a historically conditioned migration potential, related especially to post-war settlement movements (although not only). Thus, on the one hand the historical background and, on the other, the current activities make Western Pomerania one of the precursors of culturally oriented solutions to the refugee and migration issues in Poland. The importance of this issue is proved by the reading of individual texts, but also (above all) by the observations and forecasts, showing that every year the

${ }^{1}$ Dr hab. Jacek Bylica, an adjunct professor at the Department of Correctional Rehabilitation and Social Prevention of the Institute of Pedagogy of the Jagiellonian University in Kraków; ul Batorego 12, 31-135 Kraków; e-mail: jacek.bylica@uj.edu.pl. 
number of migrants (and probably refugees) on the Polish territory will increase ${ }^{2}$. The preparation of broadly understood social services, the entire aid system, individual institutions, and perhaps most of all - the society, becomes a challenge for culturally oriented social prevention. That "step forward" will make it possible to eliminate potential social problems, the occurrence of which on a certain scale can already be noticed today.

The first text of the collection Ethical and Effective Aid: Europe and Poland Facing the Refugee Issue by Marek Rymsza takes up the matter of the refugee crisis in Europe. The author points out that this crisis is not a European issue and that the solutions should be global. The war in Syria, leading to the collapse of the so-called Islamic State, requires the involvement of the international community and defining the situation becomes crucial. So far in Europe we have encountered a polarisation of positions and therefore an attitude of hospitality and hostility towards refugees/immigrants, which are reinforced by opposing media messages. Poland is rather placed in an unfavourable position to receive refugees and migrants from the Middle East. However, there is a noticeable difference between the attitudes of citizens of individual countries and those of their governments and the Catholic Church. Most activities, regardless of the position, are characterised by Eurocentrism and ethical instrumentalism, which means that, in principle, refugees are "played out" according to specific objectives.

The author proposes to build an ethical compromise between the extreme narratives, pointing out that in the future the direction of migration to Europe is inevitable, given its demographic problems, the resulting needs of the workforce ${ }^{3}$, as well as climate change. Therefore, a potential model of coexistence of cultures should be considered. According to the author, this model should be based on the principle of reciprocity, the need for a mutual "yes" to social integration. The author points out that the mixing of cultures is a greater good than their mutual separation. As you can basically agree with the author's theses, then a certain dissonance evokes the term multikulti as an extreme left-wing ideology. It seems that this type of narration, through its political connotation and ideologisation, in a way automatically creates social divisions. It would be better to talk simply about multiculturalism that is rooted in scientific discourse and reflected in

Agata Górny, Izabela Grabowska-Lusińska, Magdalena Lesińska, Marek Okólski, Transformacja nieoczywista. Polska jako kraj imigracji (Warszawa: Wydawnictwa Uniwersytetu Warszawskiego, 2010), 32-33.

Already in 2005 the European Commission's Green Paper (COM/2004/0811 final) indicated that "[...] even if the Lisbon employment targets are met by 2010, overall employment levels will fall due to demographic change. Between 2010 and 2030, at current immigration flows, the decline in the EU-25's working age population will entail a fall in the number of employed people of some 20 million. Such developments will have a huge impact on overall economic growth, the functioning of the internal market and the competitiveness of EU enterprises"; https://eur-lex.europa.eu/ legal-content/EN/ALL/?uri=CELEX\%3A52004DC0811 (access: 18.02.2020). 
intercultural education, developed successively, among others, in several centres in Poland ${ }^{4}$.

Another text by Fuad Jomma From Passive to Active Social Policy. The Shift in the Swedish Refugee Assistance System refers to the subject matter of the study through the author, who returned to Poland after his personal experience in Sweden. The text is therefore self-ethnographic and concerns the evolution of the Swedish refugee assistance system towards de facto empowerment strategy ${ }^{5}$. This is inspiring because Sweden has the largest number of refugees per million inhabitants. The original system based on social protectionism was based on care and led to the institutionalisation of refugees, defamilisation (i.e. the adoption of family functions by the state), lack of motivation to take up professional activity and learned helplessness. It also led to the establishment of cultural ghettos. Immigrants received everything, they only lacked "[...] one thing: flesh and bone Swedes"6.

The new, residual approach involves integration specialists, whose task is to work with the entire refugee family based on the so-called kulturgram (a kind of integration map). Employment after three years of apprenticeship for at least six months is considered a criterion for professional integration. Under these conditions the accommodation process in Swedish society takes about seven years. The author concludes that the main factor of integration is the willingness of both parties to have private relations. In Sweden, however this is difficult because the Swedes are individualists, which is contrary to the collective culture of the East. According to the author, Poland is between the individualistic West and the collectivist East, thus cultural proximity should guarantee integration. The question arises, however, whether cultural proximity is a sufficient condition? Looking at the situation of Ukrainians in Poland, you can have doubts about it. Therefore, cultural proximity can facilitate integration, but it does not seem to be a guarantee of integration by itself and, going further, a necessary condition.

In the next article Migration and the Ageing of the Polish Population: Challenges and Consequences Rafał Iwański shows the future of our country in the context of "demand" for immigrants. The forecasts indicate that due to the ageing of the population and the negative migration balance, the number of Polish inhabitants

4 E.g. Jerzy Nikitorowicz, "Edukacja międzykulturowa w kontekście dylematów integracji imigrantów w warunkach wielokulturowości”. In: Edukacja międzykulturowa w Polsce wobec nowych wyzwań, ed. Artur Paszko (Kraków: Willa Decjusza, 2011), 11-30.

5 Mariusz Granosik, Anita Gulczyńska, “Empowerment i badania w pracy socjalnej”. In: Empowerment w pracy socjalnej: praktyka i badania partycypacyjne, eds. Anita Gulczyńska, Mariusz Granosik (Warszawa: Centrum Rozwoju Zasobów Ludzkich, 2014), 15-23.

6 Fuad Jomma, "From Passive to Active Social Policy. The Shift in the Swedish Refugee Assistance System". In: Social Services in Work with Refugees on Polish German Cross-border Region, eds. Barbara Kromolicka, Anna Linka (Szczecin: Volumina.pl Daniel Krzanowski, 2018), 31. 
will decrease ${ }^{7}$. "Without tapping into foreign human resources [...] not only economic growth will be possible, but also the maintenance of the current standard of living"8. It will therefore be necessary to move away from the homogeneous structure of society. But you have to be prepared for that. For the time being Poland, in comparison with Western European countries, is not particularly attractive for immigrants. Policies towards economic immigrants should prevent the formation of ghettos, foster integration, counteract crimes and offences in terms of working conditions and pay, as well as other types of crime (e.g. hate crimes). Educational programmes for people working with refugees should be created and the development of cultural competences supported. In this way, separation and marginalisation, the creation of claims and learned helplessness can be prevented. Economic migrants therefore require integration support so that their migration is not merely circular or transitory. Currently in Poland such support is "demanded" by Ukrainians, culturally close immigrants, and therefore those for whom the integration should pose the least problems. It should be added that immigration policy requires a long-term view. The experience of Western countries shows that potential criminalisation particularly concerns the third generation of immigrants, which is a result of frustration and lack of perspectives, referred to as relative deprivation' 9

In the last of the theoretical articles Clash of Civilisations: An Aspect of the Migration Crisis in Europe, Piotr Briks exposes the threat to Europe posed by the Islamic civilisation. In this way he indirectly refers to Huntington's famous, somewhat historical, but still current work, in which he believed that: "The universalist aspirations of the West lead to intensified conflicts with other civilizations. The most serious are the conflicts with Islam and China" ${ }^{10}$. Interestingly, the author of the text indicates, among other things, the historical conditions of migration, including the participation (responsibility) of Western countries in creating this process. As constitutive facts for migration, he presents colonial or protectoral governments, political arrangements of the great powers after World War I and II, leaving behind chaos in countries under military intervention (e.g. Iraq). In turn, he considers the weak sense of identity in Western Europe to be a determinant

According to the Central Statistical Office (Główny Urząd Statystyczny, GUS), the birth rate of Poland's population in 2018 was the lowest in post-war history. This indicator is -26.0 and represents the difference between the number of live births and deaths of $-26,000$. The trend of negative natural growth in Poland has been observed since 2013.

${ }^{8}$ Rafał Iwański, "Migration and the Ageing of the Polish Population: Challenges and Consequences”. In: Social Services..., 46.

9 Bronisław Urban, "Procesy globalizacyjne a społeczna ekskluzja i możliwości reintegracji nowej kategorii dewiantów”. In: Różnice, edukacja, inkluzja, eds. Alicja Komorowska-Zielony, Tomasz Szkudlarek (Gdańsk: Wydawnictwo Uniwersytetu Gdańskiego, Ars Educandi Monografie, vol. 5, 2015), 264-265.

${ }^{10}$ Samuel L. Huntington, Zderzenie cywilizacji i nowy kształt ładu światowego (Poznań: Wydawnictwo Zysk i S-ka, 2018), 15. 
of the threat of Islamisation. However, this thesis can be considered somewhat controversial ${ }^{11}$. As for Islam itself, the author describes its specificity as impossible to place in the European tradition (due to fundamental cultural differences), but on the other hand he points to elements that are potentially attractive or useful for Europeans (examples of happy families, prohibition of alcohol and gambling). The article ends with the quoted statement of a Muslim radically opposed to assimilation. This opposition is, however, quite natural. Assimilation as a concept that ultimately leads to the loss of oneself, one's own identity often accompanies the representatives of the majority society ${ }^{12}$. If that Muslim had protested against integration (although the matter of its shape is still open) the case would have raised fully justified concerns.

Although the other articles in the collection present a series of practical solutions for working directly with refugees or migrants, some of them also touch on general issues. Claudia Schippel presents her many years of experience in intercultural social work in the Berlin district of Spandau in her text Refugees' Guarding and Mentoring Programs: Legal Guardianships for Unaccompanied Minors, Coaching Qualification Programs and Professional Guidance for Volunteers Working with Refugees. She presents the way and principles of operation of an individual legal guardian, the specificity of mentoring for minors and at the same time for volunteers working with refugees, who are often coping with traumatic experiences. She points to the need to supervise this work, to develop intercultural competences, to build up the ability to cope with proximity and distance, and to the importance of gender (when, for example, the volunteers are women working with male Muslim refugees). She also points to the importance of the participatory dimension of the relationship with the minor, thus ensuring his/her participation in any decision affecting him/her. She stresses the role of empathy, although here it is worth mentioning Clark's position, which questions the possibility of empathising in an intercultural encounter ${ }^{13}$.

Filip Przytulski transfers us to Poland with the text Work for Refugees. Motives, Goals, Activities of an Informal Refugees Szczecin Group. A group of social movements was formed from the bottom up as an expression of opposition to the policy of the central authorities towards refugees and the increasingly widespread xenophobic views in Poland. The purpose of its activity is to directly help

${ }^{11}$ I incline here to the statement that Rémi Brague formulates: "What is specific about European identity lies in its 'cultural secondariness': in the awareness that it is not original, but was preceded - culturally - by Greek antiquity; and religiously by Judaism". Wolfgang Welsch, "Transkulturowość. Nowa koncepcja kultury”. In: Filozoficzne konteksty rozumu transwersalnego. Wokót koncepcji Wolfganga Welscha, part 2, ed. Roman Kubicki (Poznań: Wydawnictwo Fundacji Humaniora, 1998), 212.

${ }^{12}$ Late Professor Michel Henri Kowalewicz taught his students that assimilation is swallowing, absorption of the Other.

${ }_{13}$ Janet Clark, "Beyond Empathy: An Ethnographic Approach to Cross-cultural Social Work Practice", http://www.mun.ca/cassw-ar/papers2/clark.pdf (access: 22.02.2020). 
refugees, as well as to build public awareness in this matter. The members of Refugees Szczecin believe that refugees - as Jews before - are a personification of evil for part of society. In criminological literature this is reflected in the figure of the "deviant immigrant" and is related to the change in social moods towards Others in many European countries ${ }^{14}$. As a panacea to change the situation, the author proposes the recognition of different cultural identities and respect for universal values within the cultural universe. The problem is that the so-called universal values are usually perceived from the perspective of Western culture, and the cultural universe usually (and in this case certainly) has its subuniverses ${ }^{15}$. In practical terms, the group collects gifts for people staying in refugee and foreigners' centres in Germany and Poland, organises debates with refugees, demonstrations and protests, as well as educational activities for young people. The group's activity can therefore be described as pioneering in the country on the Vistula River; however, it is worth noting that through the "opposition awareness" its activities are part of the struggle and thus the polarisation of positions in Poland. The author also points out that the constitution of the group's identity took place in a classic way, i.e. on the basis of "us-them" opposition ${ }^{16}$.

Another article from the collection touches upon the particularly difficult area of international organised crime. Monika Grötzinger, a social worker in Berlin, presents the text Working with Victims of Human Trafficking from Africa: An Example of the SOLWODI Organization. The organization deals with women who are victims of human trafficking, forced prostitution and violence. Often these women come originally with other problems such as lack of a residence permit, high-risk pregnancies, homelessness and incomprehensible documents. Only after some time does the essence of their case come to light. SOLWODI (Solidarity with Women in Distress) therefore deals with culturally sensitive psychosocial counselling aimed at dealing with trauma. It examines resources to bring about psychosocial stabilisation of the victims. It also provides support in legal proceedings against human traffickers, applying the principle of empowerment in its work. Some of the African women are in the cultural psychological trap of a voodoo ritual that they try to break assisted by organization employees. The ultimate goal of these efforts is to achieve social integration in Germany or to organise and support the return to the country of origin. SOLWODI also lectures on human trafficking. The importance of the fact that students of the University of Szczecin

${ }^{14}$ Katja F. Aas, Globalization \& Crime (Los Angeles-London-New Delhi-Singapore: Sage Publications, 2006), 75-100.

15 Adam Lech, "Społeczne konstruowanie rzeczywistości obiektywnej”, Zeszyty Naukowe Politechniki Śląskiej. Organizacja i Zarządzanie 65 (2013), 183-195.

16 Tomasz Szkudlarek, "Pedagogika międzykulturowa". In: Pedagogika. Podręcznik akademicki, vol. 1, eds. Zbigniew Kwieciński, Bogusław Śliwerski (Warszawa: PWN, 2003), 421-424. 
also participate in it should be stressed, as this area appears to be a special challenge for social services.

The next article is by the co-editor of Anna Linka's volume Hostipitality Kana Theatre Centre and the Issue of Refugees and "Migration Crisis". A Pedagogical Perspective ${ }^{17}$ deserves recognition. It is a collection of important and in-depth reflections on the subject. The author points to the importance of entering the cultural, mental and reflective borderland. In this way, it turns the reader towards a border pedagogy in which both teachers and pupils are included in the category of "border-crossers"18. On the basis of Jacques Derrida's neologism (Hostility/ Hospitality), she emphasises an intrapsychic view of the problem of exile. To welcome a guest, you must first accept the stranger within yourself. It is therefore necessary to deepen the awareness of oneself, one's own culture and its diversity. However, currently in Poland, differences in world views have become the basis for building one's own identity. "[...] we are strange to ourselves. Another Polish person with a different worldview is for us the 'Other"'19. Thus, the basis for wider cultural integration is integration at the family, neighbourhood, local and regional level. Unfortunately, it seems that Polish society still bears the legacy of communism, which means that the adversary is usually treated with superiority and only one political party/side of the dispute has a monopoly on the right truth. Therefore the author comes to the conclusion that rational arguments in the current situation are no longer sufficient. Crossing the border requires emotional, spiritual and extra-national elements provided by creative expression.

Romuald Zańko, a member of the Pod Sukniami Foundation and a traveller, has observed an increase in aversion and hostility to refugees in Polish society. The article Aid to the Civilian Victims of the War in Syria as a 'Living Monument' of the Warsaw Uprising presents the actions of humanitarian aid organisations in 2014 in the context of commemorating the $70^{\text {th }}$ anniversary of the uprising in the Polish capital. During the event, the organisers met with various social reactions, in which indifference prevailed. The generation of Varsovians who remember the war welcomed the action. After a year, at the next fund-raising, negative attitudes and hostility appeared in social reactions in addition to indifference. The author considers the lack of information in the media as one of the reasons for such attitudes. One has to agree that there is a lack of reliable information on the subject in public discourse. It also seems that the war in Syria is presented

17 The Kana Theatre Centre projects go beyond a strict artistic understanding of creativity. They emphasise the educational dimension, giving culture a primary socialising function. They are located in the flow of intercultural pedagogy.

${ }^{18}$ Henry A. Giroux, "Pedagogia pogranicza w wieku postmodernizmu". In: Edukacja i sfera publiczna. Idee i doświadczenia pedagogiki radykalnej, eds. Henry A. Giroux, Lech Witkowski (Kraków: Oficyna Wydawnicza „Impuls”, 2018), 221-242.

19 Anna Linka, "Hostipitality - Kana Theatre Centre and the Issue of Refugees and 'Migration Crisis'. A Pedagogical Perspective”. In: Social Services..., 114. 
to Polish citizens as a distant matter. And although the Polish Humanitarian Action warned that Poles were reluctant to help the victims of wars (the same is true for the whole world), the organisers of the undertakings were accompanied by a feeling of disappointment.

Another text My Way from Syria to Germany contains the bitter words of a refugee. Hamad Alramadan, a Syrian refugee and journalist, has been prosecuted by the Syrian government regime, ISIS and al-Qaeda for informing the world about the crimes committed by the parties to the conflict. After reaching Germany, he and others were settled in a camp where refugees were treated as prisoners, controlling their every step; they could not make decisions for themselves and they were expected to communicate fluently in German. In fact, detention centres for immigrants and asylum seekers have already been called the new carcelar archipelago ${ }^{20}$. The author stresses that Syrians come to Europe to survive; in reality they would like to return to their country. But today in Syria they are dying because they want freedom. In his opinion any external force that engages in the conflict deepens it, killing civilians. In turn, "[...] the integration, which European governments want is to get the human machines to work. Not integration with European society and way of living" ${ }^{21}$. His view is therefore in line with the optics of ethical instrumentalism, signalled in the first text of the collection ${ }^{22}$.

Agnieszka Radłowska presents Challenges of Teaching a Language in a Multicultural Refugee Group, for which German was the first written language and participants had to learn Latin letters. This is a particular problem because there is no language in working with such a group that can be shared by all course participants and the facilitator. The author therefore led the group intuitively; at the beginning, her Polish origin was also helpful, as she, like refugees, came from another country. The course participants were very determined to learn, knowing that their life and future in their new country depend on their language skills. They also met outside the course, which contributed to building informal contacts. In the end, the facilitator befriended the group, going beyond her formal role, often offering her own advice. Thus, learning the language of the host country is an essential part of the process of social-cultural integration.

In the next two texts Paweł Glapiński and Joanna Smaglo-Yildirim present the activities of the Polish Social Council in Berlin. The Council is the largest self-help organisation among immigrant organisations in Germany. It supports social integration of immigrants mainly from Poland, but also from Eastern Europe. The support is done by informing about the specifics of the German legal, social and educational system, providing psychological and legal advice, as well as

20 Michael Welch, Liza Schuster, "Detention of Asylum Seekers in the US, UK, France and Italy: A Critical View of the Globalizing Culture of Control”, Criminal Justice 5 (4) (2005), 331-355.

21 Hamad Alramadan, "My Way from Syria to Germany". In: Social Services..., 127.

22 Marek Rymsza, "Ethical and Effective Aid: Europe and Poland Facing the Refugee Issue". In: Social Services..., 23. 
professional training. Migration guidance should not last longer than three years, and one of the indicators of its effectiveness is the public activity of the participants and the continuation of vocational training. The Council's idea is that integration assistance should be provided by people who have themselves undergone a path of adaptation to the new social-cultural reality. The Council therefore organises volunteer assistance for refugees, including minors, on a mentoring basis. This assistance often concerns everyday activities such as arranging a doctor's appointment, getting to know the specifics of public transport or convenient places for shopping. This kind of activity - apart from direct assistance to migrants and refugees - makes the Council part of Berlin society.

In the penultimate text, Kerstin Zablocki shows the way From German Classes to Thorough Aid for Refugees on the basis of her own activity in the "Pasewalk hilft!" group. She confirms that refugees are strongly motivated to learn German, which is becoming a foreground for other forms of assistance, such as finding a new apartment. Refugees, after obtaining a residence permit, have one month to leave their existing premises. This is quite a short period of time, considering that they do not have contacts in the new country, which is accompanied by the feeling that they are not liked by the natives. There are also other types of problems, such as opening a bank account. Therefore, assistance is often provided through private contacts of the members of "Pasewalk hilft!", which is consistent with the profile of the group.

The publication ends with a report by Anna Linka from the conference In Search of the Perfect Balance. Poland and Europe in the Face of the Migration Crisis and the project Earnestly about Refugees: More Knowledge, Less Emotions conducted by the Association "Kreatywni dla Szczecina i Regionu" (Creatives for Szczecin and the Region). The topics of the speeches concerned, among others, media discourse in Poland towards migrants, possibilities of adaptation of Muslim refugees to the European culture, analysis of attitudes of Polish society towards migrants, and European legal regulations concerning the migration crisis. The project also included the development of educational materials for students of primary and lower secondary schools, as well as employees of public institutions. In addition, training on working in a multicultural environment was organised, as well as school debates with the participation of migrants in the formula of the Oxford debate.

To sum up, this work, taking up the refugee and migration issue in many aspects, seems to be a pioneering one in Poland. Its advantage is that by presenting practical solutions applied abroad, it inspires both Polish pedagogical thought and practice. It also presents social moods towards the refugee/migration crisis, while at the same time creating proposals for solutions. Particularly interesting seems to be the intrapsychic look at the attitude of Poles (although obviously not only) towards the figure of the Other and the identity function of the "us-them" relationship. An unquestionable advantage of the work is also its bilingualism, 
allowing for a wider reception of the presented issues. However, there is a mistake in the title on the cover of the book, where "polish german" is written in small letters. In addition, a certain lack of interpretation of cultural processes results in a lack of reference to the idea of transculturality ${ }^{23}$. Although some of the texts contain references to multi- or interculturality, these well-established theories do not create a new space of interpretation. On the other hand, it should be noted that transculturality appears in some moments of work in the implicit formula. Finally, it is worth emphasising once again the topicality of the issues raised, although it is difficult to predict the further course of events on the migration and refugee issue in the era of coronavirus.

\section{References}

Aas, Katja F. Globalization \& Crime. Los Angeles-London-New Delhi-Singapore: Sage Publications, 2006.

Alramadan, Hamad. "Moja droga z Syrii do Niemiec”. In: Służby społeczne w pracy z uchodźcami na pograniczu polsko-niemieckim, eds. Barbara Kromolicka, Anna Linka. Szczecin: Volumina.pl Daniel Krzanowski, 2018, 127-129.

Clark, Janet. "Beyond Empathy: An Ethnographic Approach to Cross-cultural Social Work Practice", http://www.mun.ca/cassw-ar/papers2/clark.pdf (access: 22.02.2020).

Giroux, Henry A. "Pedagogia pogranicza w wieku postmodernizmu”. In: Edukacja i sfera publiczna. Idee i doświadczenia pedagogiki radykalnej, eds. Henry A. Giroux, Lech Witkowski. Kraków: Oficyna Wydawnicza “Impuls”, 2018, 221-242.

Górny, Agata, Grabowska-Lusińska, Izabela, Lesińska, Magdalena, Okólski, Marek. Transformacja nieoczywista. Polska jako kraj imigracji. Warszawa: Wydawnictwa Uniwersytetu Warszawskiego, 2010.

Granosik, Mariusz, Gulczyńska, Anita. "Empowerment i badania w pracy socjalnej”. In: Empowerment $w$ pracy socjalnej: praktyka i badania partycypacyjne, eds. Anita Gulczyńska, Mariusz Granosik. Warszawa: Centrum Rozwoju Zasobów Ludzkich, 2014, 15-23.

Green Paper, COM/2004/0811 final, https://eur-lex.europa.eu/legal-content/EN/ALL/?uri=CELEX\% 3A52004DC0811 (access: 18.02.2020).

Huntington, Samuel L. Zderzenie cywilizacji i nowy kształt ładu światowego. Poznań: Wydawnictwo Zysk i S-ka, 2018.

Iwański, Rafał. "Migracje a proces starzenia się ludności Polski - wyzwania i konsekwencje”. In: Stużby społeczne w pracy z uchodźcami na pograniczu polsko-niemieckim, eds. Barbara Kromolicka, Anna Linka. Szczecin: Volumina.pl Daniel Krzanowski, 2018, 39-48.

Jomma, Fuad. “Od pasywnej do aktywnej polityki społecznej. Zwrot w szwedzkim systemie pomocy uchodźcom”. In: Stużby społeczne w pracy z uchodźcami na pograniczu polsko-niemieckim, eds. Barbara Kromolicka, Anna Linka. Szczecin: Volumina.pl Daniel Krzanowski, 2018, 27-38.

Lech, Adam. "Społeczne konstruowanie rzeczywistości obiektywnej”. Zeszyty Naukowe Politechniki Śląskiej. Organizacja i Zarządzanie 65 (2013), 183-195.

Linka, Anna. "Wro/gościnność - ośrodek teatralny 'Kana’ wobec problemu uchodźstwa i 'kryzysu migracyjnego"'. In: Służby społeczne $w$ pracy z uchodźcami na pograniczu polsko-niemieckim, eds. Barbara Kromolicka, Anna Linka. Szczecin: Volumina.pl Daniel Krzanowski, 2018, 101-117.

23 Welsch, “Transkulturowość...”, 195-222. 
Nikitorowicz, Jerzy. "Edukacja międzykulturowa w kontekście dylematów integracji imigrantów w warunkach wielokulturowości”. In: Edukacja międzykulturowa w Polsce wobec nowych wyzwań, ed. Artur Paszko. Kraków: Willa Decjusza, 2011, 11-30.

Rymsza, Marek. “Jak pomagać etycznie i skutecznie. Europa i Polska wobec kwestii uchodźczej”. In: Służby społeczne w pracy z uchodźcami na pograniczu polsko-niemieckim, eds. Barbara Kromolicka, Anna Linka. Szczecin: Volumina.pl Daniel Krzanowski, 2018, 13-26.

Szkudlarek, Tomasz. "Pedagogika międzykulturowa”. In: Pedagogika. Podręcznik akademicki, vol. 1, eds. Zbigniew Kwieciński, Bogusław Śliwerski. Warszawa: PWN, 2003, 415-424.

Urban, Bronisław. "Procesy globalizacyjne a społeczna ekskluzja i możliwości reintegracji nowej kategorii dewiantów”. In: Różnice, edukacja, inkluzja, eds. Alicja Komorowska-Zielony, Tomasz Szkudlarek. Gdańsk: Wydawnictwo Uniwersytetu Gdańskiego, Ars Educandi Monografie, vol. 5, 2015, 257-267.

Welch, Michael, Schuster, Liza. "Detention of Asylum Seekers in the US, UK, France and Italy: A Critical View of the Globalizing Culture of Control". Criminal Justice, 5 (4) (2005), 331-355.

Welsch, Wolfgang. “Transkulturowość. Nowa koncepcja kultury”. In: Filozoficzne konteksty rozumu transwersalnego. Wokót koncepcji Wolfganga Welscha, part 2, ed. Roman Kubicki. Poznań: Wydawnictwo Fundacji Humaniora, 1998, 195-222. 